\title{
Chilli Growers in Raipur District: Study about Socio-Economic and Psychological Attributes
}

\author{
S.K. Verma ${ }^{1}$, D.P. Rai ${ }^{2}$, B.P. Tripathi ${ }^{3}$ and K.K. Pandey ${ }^{4}$ \\ ${ }^{1}$ Dy. Project Director (ATMA), District - Kabirdham (Chhattisgarh), India \\ ${ }^{2}$ Department of Technology Transfer, MGCG Vishwavidhyalaya, \\ Chitrakoot-Satna (M.P.), India \\ ${ }^{3}$ KVK, Kawardha, Kabirdham (Chhattisgarh), India \\ ${ }^{4}$ Ag. Statistics, DKS College of Agri. \& Res. Station, Bhatapara (Chhattisgarh), India \\ *Corresponding author
}

\section{A B S T R A C T}

\begin{tabular}{|l|}
\hline Ke y w o r d s \\
Age, \\
Cosmopoliteness \\
Psychological and \\
Socio-Economic \\
Attributes \\
\hline Article Info \\
\hline $\begin{array}{l}\text { Accepted: } \\
\text { xx November } 2018 \\
\text { Available Online: } \\
\text { xx December } 2018\end{array}$ \\
\hline
\end{tabular}

\section{Introduction}

Agriculture has been and will continue it be the life line of the Indian economy. As the largest private enterprise in India, agriculture contributes nearly one fourth of the national G.D.P., sustains livelihood of about two third of the population and is the backbone of agrobased industry. In food sector alone agriculture contributes about 250 thousand corers rupees annually. Since 1950, the productivity gain is nearly 3.3 times in food
The present study covers the Socio-Economic and Psychological Attributes of Chilli Grower farmers of Raipur District. Under the study 12 variables were used to collect the data and for interpretation of the study. These 12 variables classified into three heads Social Economic and Psychological. The mean and percentage used to analyses the data. The chilli growers 39.17 per cent were of middle age group, 45.83 per cent of respondents were found to possess primary school level of education, 40.83 per cent belonged to SC/ST category and 38.33 per cent had low social participation. Chilli growers 34.17 per cent had medium size of land holding, majority 55.83 per cent were in the medium socioeconomic status category, 39.17 per cent were in the medium economic motivation category, 48.33 per cent were in the medium risk preference category, majority 53.33 per cent were in the medium cosmopoliteness category. 
Horticulture sector covering only 8.00 per cent of total crop area in the country, contributes 24.50 per cent to G.D.P. and 54.55 per cent to export earning in agriculture sector (Chadha, 2001).

India has favorable climate and soils for growing a large number of horticultural crops which includes vegetables, fruits, ornamental plants, medicinal plants, aromatic plants and spices etc. It is the largest producer, consumer and exporter of spices and spice based products in the world. Thus, India is on a brink of golden revolution in horticulture.

\section{Materials and Methods}

Raipur District is situated in the fertile plains of Chhattisgarh Region. This District is situated between $22^{0} 33^{\prime} \mathrm{N}$ to $21^{\circ} 14^{\prime} \mathrm{N}$ Latitude and $82^{\circ} 6^{\prime}$ to $81^{\circ} 38^{\prime} \mathrm{E}$ Longitude. The District is surrounded by District Bilaspur in North, District Bastar and part of Orissa state in South, District Raigarh and part of Orissa state in East and district Durg in West. The district occupies the south eastern part of the upper Mahanadi valley and the bordering hills in the south and the east. Thus, the district is divided into two major physical divisions, Viz., the Chattisgarh plain and the Hilly Areas.

\section{Variables under study}

(1) Age (2) Education (3) Caste (4) Social participation (5) Size of land holding (6) Socio-economic status (7) Economic motivation (8) Risk preference (9) Cosmopoliteness (10) Attitude towards improved farm practices (11) Innovativeness (12) Management orientation.

These variables classified into the following heads:

1. Social 2. Economic 3. Psychological

\section{Statistical analysis of data}

Data collected were qualitative as well as quantitative. The quantitative data were interpreted in terms of percentage and qualitative data were tabulated on the basis of categorization methods.

After tabulation, percentage, mean, standard deviation, correlation coefficient and multiple regression analysis was carried out.

\section{Percentage}

The term 'percentage' means a fraction whose denomination is 100 and the numeration of the fraction is called percentage. For calculating percentage, frequency was multiplied by 100 and divided by total respondents.

$P=\frac{X}{N} x 100$

Where,

$\mathrm{P} \quad=\quad$ Percentage

$\mathrm{X}=$ Frequency of respondents

$\mathrm{N}=$ Total number of respondents

\section{Mean}

Mean was obtained by dividing the sum of the scores by the total number of respondents, according to the following formula -

$$
\overline{\mathrm{X}}=\frac{\sum \mathrm{X}_{\mathrm{i}}}{\mathrm{n}}
$$

Where,

$\mathrm{X}=$ Mean

$\sum \mathrm{Xi}_{\mathrm{i}}=$ Sum of all the pairs in a distribution

$\mathrm{n}=$ Total number of items involved.

\section{Results and Discussion}

The data regarding socio-economic, communicational and psychological attributes 
of chilli growers were analyzed and their basic statistical values are presented from Table 1 to 3.

\section{Age}

The data presented in table 1 reveals that out of the total 120 respondents most of them 39.17 per cent were of middle age group followed by old age group 32.50 per cent and young age group 28.33 per cent. The mean score of young age group was $0.58,0.80$ for middle age group and 0.66 for old age group. The overall mean score was 2.04.

\section{Education}

The data shows that maximum numbers 45.83 per cent of respondents were found to possess primary school level of education, 10.83 per cent were illiterates, 16.67 per cent were functionally literate, 16.67 per cent had middle school education. The high school level of education was obtained by only 10.00 per cent of respondents. The category wise mean score was 0.21 for illiterate, 0.33 for functionally literate, 0.91 for primary school, 0.33 for middle school and 0.20 for high school level education. The overall mean score was 1.98.

\section{Caste}

The data in regarding caste of respondents are presented in Table 1 and depicts that most of the chilli growers 40.83 per cent belonged to SC/ST category followed by 35.00 per cent belonging to OBC category and 24.17 per cent belonged to General category. The category wise mean score was 0.75 for SC/ST, 0.64 for $\mathrm{OBC}$ and 0.44 for General. The overall mean score was 1.83 .

\section{Social participation}

The data in table 1 shows that out of the total 120 members of chilli growers, most of them
38.33 per cent had low social participation, followed by 33.33 per cent in medium social participation and only 28.34 per cent were found in high social participation. The overall mean score was found to be 1.90 . The mean score of the low social participation category was found to be 0.73 while that of the medium and high category were 063 and 0.54 respectively.

\section{Size of land holding}

The data in table 2 shows that out of the total 120 respondents, the most of them 34.17 per cent had medium size of land holding. In small size of land holding the respondents were 31.67 per cent, followed by marginal category 20.83 per cent, and in large category 13.13 per cent. The overall mean score of size of holding was found to be 2.40 . The mean score of size of land holding were 0.50, 0.76, 0.82 and 0.32 in respect of marginal, small, medium and large size categories respectively.

\section{Socio-economic status}

The data shows that out of the total 120 respondents, the majority 55.83 per cent were in the medium socio-economic status category followed by 25.00 per cent in low socioeconomic group while only 19.17 per cent were in high socio-economic status group. The overall mean score was found to be 11.87 . The mean scores of socio-economic status were 2.97, 6.63 and 2.27 for low, medium and high socio-economic status categories respectively.

\section{Economic motivation}

The data in table 2 shows that out of the total 120 respondents, 37.50 per cent were in the low economic motivation category, while 39.17 per cent were in the medium economic motivation category and only 23.33 per cent were in high economic motivation category. The mean score of the low economic 
motivation category was found to be 1.63 while that of the medium economic motivation category was 1.70 and 1.01 for high economic motivation category. The over all mean score was found to be 4.34 .

\section{Risk preference}

The data in table 2 shows that out of the total 120 respondents, 29.17 per cent were in the low risk preference category, while 48.33 per cent were in the medium risk preference category and only 22.50 per cent were in high risk preference category. The mean score of the low risk preference category was 1.31 while that of the medium risk preference category was 2.39 and high category was 1.11. The overall mean score of risk preference category was 4.93 .

\section{Cosmopoliteness}

The data in table 2 shows that out of the total 120 respondents, the majority 53.33 per cent were in the medium cosmopoliteness category followed by 33.33 per cent were in the low cosmopoliteness category and only 13.34 per cent were in high cosmopoliteness category. The mean score of the low cosmopoliteness category was found to be 0.60 while that of the medium category was 0.96 and high category was 0.24 . The overall mean score of cosmopoliteness was found to be 1.80 .

\section{Attitude towards improved farm practices}

Table 3 shows that out of the total 120 respondents, higher percentage of respondents were in low category of attitude towards improved technology followed by 33.33 per cent respondents in the medium category and 25.84 per cent in high category. The mean score of the low attitude towards improved technology was found to be 0.75 , followed by 0.62 and 0.48 for medium and high categories respectively. The overall mean score was 1.85 .

Table.1 Distribution of respondents according to their social attributes (Social attributes of chilli growers)

\begin{tabular}{|c|c|c|c|c|c|}
\hline S.No. & Attributes & Categories & No. of respondents & Percentage & Mean score \\
\hline \multirow[t]{4}{*}{1.} & \multirow{4}{*}{ Age } & Young & 34 & 28.33 & 0.58 \\
\hline & & Middle & 47 & 39.17 & 0.80 \\
\hline & & Old & 39 & 32.50 & 0.66 \\
\hline & & Total & 120 & 100 & 2.04 \\
\hline \multirow[t]{6}{*}{2.} & \multirow[t]{6}{*}{ Education } & Illiterate & 13 & 10.83 & 0.21 \\
\hline & & Functionally literate & 20 & 16.67 & 0.33 \\
\hline & & Primary school & 55 & 45.83 & 0.91 \\
\hline & & Middle School & 20 & 16.67 & 0.33 \\
\hline & & High school & 12 & 10.00 & 0.20 \\
\hline & & Total & 120 & 100 & 1.98 \\
\hline \multirow[t]{4}{*}{3.} & \multirow[t]{4}{*}{ Caste } & ST/SC & 49 & 40.83 & 0.75 \\
\hline & & $\mathrm{OBC}$ & 42 & 35.00 & 0.64 \\
\hline & & General & 29 & 24.17 & 0.44 \\
\hline & & Total & 120 & 100 & 1.83 \\
\hline \multirow[t]{4}{*}{4.} & \multirow[t]{4}{*}{ Social participation } & Low & 46 & 38.33 & 0.73 \\
\hline & & Medium & 40 & 33.33 & 0.63 \\
\hline & & High & 34 & 28.34 & 0.54 \\
\hline & & Total & 120 & 100 & 1.90 \\
\hline
\end{tabular}


Table.2 Distribution of respondents according to their economic attributes (Economic attributes of Chilli growers)

\begin{tabular}{|c|c|c|c|c|c|}
\hline S.No. & Attributes & Categories & $\begin{array}{c}\text { No. of } \\
\text { respondents }\end{array}$ & Percentage & $\begin{array}{l}\text { Mean } \\
\text { score }\end{array}$ \\
\hline \multirow[t]{5}{*}{1.} & \multirow[t]{5}{*}{ Size of land holding } & Marginal farmers & 25 & 20.83 & 0.50 \\
\hline & & Small farmers & 38 & 31.67 & 0.76 \\
\hline & & Medium farmers & 41 & 34.17 & 0.82 \\
\hline & & Large farmers & 16 & 13.33 & 0.32 \\
\hline & & Total & 120 & 100 & 2.40 \\
\hline \multirow[t]{4}{*}{2.} & \multirow[t]{4}{*}{ Socio economic status } & Low & 30 & 25.00 & 2.97 \\
\hline & & Medium & 67 & 55.83 & 6.63 \\
\hline & & High & 23 & 19.17 & 2.27 \\
\hline & & Total & 120 & 100 & 11.87 \\
\hline \multirow[t]{4}{*}{3.} & \multirow[t]{4}{*}{ Economic motivation } & Low & 45 & 37.50 & 1.63 \\
\hline & & Medium & 47 & 39.17 & 1.70 \\
\hline & & High & 28 & 23.33 & 1.01 \\
\hline & & Total & 120 & 100 & 4.34 \\
\hline \multirow[t]{4}{*}{4.} & \multirow[t]{4}{*}{ Risk preference } & Low & 35 & 29.17 & 1.31 \\
\hline & & Medium & 58 & 48.33 & 2.39 \\
\hline & & High & 27 & 22.50 & 1.11 \\
\hline & & Total & 120 & 100 & 4.93 \\
\hline \multirow[t]{4}{*}{5.} & \multirow[t]{4}{*}{ Cosmopoliteness } & Low & 40 & 33.33 & 0.60 \\
\hline & & Medium & 64 & 53.33 & 0.96 \\
\hline & & High & 16 & 13.34 & 0.24 \\
\hline & & Total & 120 & 100 & 1.80 \\
\hline
\end{tabular}

Table.3 Distribution of respondents according to psychological attributes (Psychological attributes of chilli growers)

\begin{tabular}{|c|c|c|c|c|c|}
\hline S.No. & Attributes & Categories & No. of respondents & Percentage & Mean Score \\
\hline \multirow[t]{4}{*}{1.} & \multirow{4}{*}{$\begin{array}{l}\text { Attitude towards improved } \\
\text { technology }\end{array}$} & Low & 49 & 40.83 & 0.75 \\
\hline & & Medium & 40 & 33.33 & 0.62 \\
\hline & & High & 31 & 25.84 & 0.48 \\
\hline & & Total & 120 & 100 & 1.85 \\
\hline \multirow[t]{4}{*}{2.} & \multirow[t]{4}{*}{ Innovativeness } & Low & 32 & 26.67 & 1.52 \\
\hline & & Medium & 65 & 54.17 & 3.09 \\
\hline & & High & 23 & 19.16 & 1.09 \\
\hline & & Total & 120 & 100 & 5.70 \\
\hline \multirow[t]{4}{*}{3.} & \multirow[t]{4}{*}{ Management orientation } & Low & 48 & 40.00 & 1.83 \\
\hline & & Medium & 54 & 45.00 & 2.06 \\
\hline & & High & 18 & 15.00 & 0.69 \\
\hline & & Total & 120 & 100 & 4.58 \\
\hline
\end{tabular}




\section{Innovativeness}

The data in table 3 shows that out of the total 120 respondents, majority of the respondents 54.17 per cent were in medium innovativeness category followed by 26.67 per cent in low category and only 19.16 per cent in high category. The mean score of the low innovativeness category was 1.52 while that of the medium innovativeness category was 3.09 and high category was 1.09.The overall mean score was 5.70 .

\section{Management orientation}

The data in Table 3 shows that out of the total 120 respondent, 40.00 per cent were in the low management orientation category, 45.00 per cent in medium category, and only 15.00 per cent in high category. The mean score of the low management orientation category was 1.83 while that of the medium management orientation category was 2.06 and high category was 0.69 . The overall mean score was 4.58.

It revealed from the presented study that the higher percentage of respondents was found in middle age group. Similar findings were also reported by Upadhyaya (1993), Vidhate (1997), Vankar (2000), Christian (2001), Dongardive (2002) and Toppo (2005).

Most of the respondents had education up to primary level. The above finding is in accordance with the findings of Patel (1995).

It observed from the presented study that highest number of chilli growers belonged to SC/ST category.

Most of the respondents had low social participation.

A higher percentage of the chilli growers had medium size of land holding. Similar findings were also reported by Deokate (1998) and Christian (2001).
The majority of respondents were found in medium socio-economic status category. The present finding confirms the result of Adhikari (2007) and Chouhan (2007).

Most of the respondents were found in medium risk preference category. Similar findings were also reported by Valand (1997), Patel (2000) and Vankar (2000).

Most of the respondents had low attitude towards improved technology.

The majority of chilli growers were found in medium innovativeness category.

Higher percentage of respondents was found in medium management orientation category. Yadav (2001) revealed the similar finding.

In conclusion, it revealed from the present study that most of the chilli growers 39.17 per cent were of middle age group, 45.83 per cent of respondents were found to possess primary school level of education, 40.83 per cent belonged to SC/ST category and 38.33 per cent had low social participation.

It was observed that most of the chilli growers 34.17 per cent had medium size of land holding, majority 55.83 per cent were in the medium socio-economic status category, 39.17 per cent were in the medium economic motivation category, 48.33 per cent were in the medium risk preference category, majority 53.33 per cent were in the medium cosmopoliteness category.

\section{References}

Adhikari, G. (2007). Knowledge and adoption behaviour of rice growers in Hoshangabad district of Madhya Pradesh. An unpublished M.Sc. (Ag.) Thesis, R.A.K. College of Agriculture, J.N.K.V.V., Jabalpur. 
Barodia, A.R. (2005). A study on adoption behaviour of vegetable growers in relation to improved technology in Funda block of Bhopal district. (M.P.). Unpublished M.Sc. (Ag) thesis, JNKVV, Jabalpur.

Chouhan, D. K. (2007). "A study of the technological knowledge possessed by the tribal cotton growers and its adoption in Manawar block of District Dhar (M.P.)". M.Sc. (Ag.) Thesis (Unpublished), R.A.K. COA, JNKVV, Jabalpur.

Christian, B.M. (2001). A study on extent of adoption of IPM strategy by cotton growers of Vadodara district of Gujarat State. Unpublished M.Sc. (Agri.) thesis, G.A.U., Anand Campus, Anand.

Deotale, S. L., Choudhry, M. R., Tidke, G. R. and L. D. Nagalwade (1994). Adoption behaviour among vegetable growers in Nagpur district. Journal of Soil and Crops. 4 (2): 141-144.

Diwan, Y.B. (2000). Study on Role performance of Tribal farm women in adoption of Maize production technology in Dahod district of Gujarat state. M.Sc. (Agri.) thesis, G.A.U., Anand Campus, Anand.

Dongardive, V.T. (2002). A study on adoption of recommended technology of chilli growers in Anand district of Gujrat state. M.Sc. (Ag.) thesis, Unpublished. G.A.U., Anand campus, Anand.

Kushwaha, and A.K. Pandey (1998). Differential attributes of potato growers in relation to their adoption behaviour. Madhya. J. Extn. Edu. 1(1):53-56.

Kushwaha C.L, Ramganesh, Singh, V.B and O.P. Daipuria (2004). Knowledge of Solanicious vegetable growers towards plant protection measures- A correlation and path analysis. $2^{\text {nd }}$ National Extension Education Congress. Society of Extension Education, Agra \&
MPUAT, Udaipur. pp 63-64.

Painkra, S.K; Chouhan, A.S and K.J. Thombre (2005). Knowledge and adoption gap formers towards weed technology presented in third National Extension Education Congress, April 27-29. Society of Extension Education, Agra. ENDRI, Karnal. 158-159.

Parashar, A.N. (2004). A study on adoption of rose cultivation in Vadodara district of Gujarat state. M.Sc. (Agri.) thesis, A.A.U., Anand Campus, Anand.

Patel, B.J. (1995). A study on adoption behaviour of kharif paddy growers in relation to recommended plant protection measures in Panchamahal district of Gujarat. M.Sc. (Agri.) thesis, G.A.U., Sardar krushinagar.

Patel, R.C. (2000). A study on the consequences of adoption of watershed management technology by beneficiary farmers in watershed area of Kheda district of Gujarat state. Ph.D. thesis, G.A.U., Anand Campus, Anand.

Tomar, J. S. (2005). A study on knowledge and adoption of Barseem production technology in Ashta block of Sehore district. M.Sc. (Ag.) thesis. R.A.K.COA, JNKVV, Jabalpur.

Toppo (2005). A study of participation and Decision making of farm women in Dairy occupation. M.Sc. (Agri.) thesis, A.A.U., Anand Campus, Anand.

Upahayaya, J.N (1993). A study on prospectus of orchard and vegetable growing under present farming system in Rewa district, M.P. Msc. Ag. Thesis J.N.K.V.V College of Agriculture Rewa. pp 86.

Vaidhya, A.C. (2004). A study of farmer's awareness regarding agricultural pollution in Gujarat. M.Sc. (Agri.) thesis, A.A.U., Anand Campus, Anand.

Valand, B.S. (1997). Impact of integrated pest management on Kharif paddy growers in Kheda district of Gujarat State. M.Sc. 
(Agri.) thesis, G.A.U., Anand Campus, Anand.

Vankar, P.M. (2000). Impact of canal irrigation on schedule caste farmers in Khambat Taluka of Anand District of Gujarat State. M.Sc. (Agri.) thesis, G.A.U., Anand Campus, Anand.

Vidhate, S. B. (1997). A study of ginger growers in Satara district, M.Sc. (Agri.) thesis. M.P.K.V., Rahuri (M.S.).

Vankar, P.M. (2000). Impact of canal irrigation on schedule caste farmers in Khambat Taluka of Anand District of Gujarat State. M.Sc. (Agri.) thesis, G.A.U., Anand Campus, Anand.

\section{How to cite this article:}

Verma, S.K., D.P. Rai, B.P. Tripathi and Pandey, K.K. 2018. Chilli Growers in Raipur District: Study about Socio-Economic and Psychological Attributes. Int.J.Curr.Microbiol.App.Sci. 7(12): 1723-1730. doi: https://doi.org/10.20546/ijcmas.2018.712.200 